\title{
Facing Europeanism
}

The critical attention for Europeanism as an ideology with the purpose of constructing the European Union as a political and cultural unity, is a fairly recent phenomenon in archaeology. In this issue of Archaeological dialogues, Europeanism is conceived by Alexander Gramsch as an attempt by European elites to create a supra-national European identity which replaces the existing national identities. One of the most important ways to reach this end consists of stressing a shared past and a common cultural heritage. It is precisely here that archaeology is supposed to be in a position of playing an important role, because it would have the ability to demonstrate the pan-European character of prehistoric and early historic cultures. In the past few years archaeology has indeed been used for such a political end. Under the auspices of 'Europe' several large exhibitions have been organized which successively tried to assess the meaning of bronze age cultures, the Celts and the Franks for the formation of a common European identity. Many archaeologists have participated in these projects, whereas others have criticized the political nature of such enterprises. By using the term 'Europeanism', Gramsch wants to show that the strategy to involve the remote past in a process of cultural legitimatization of the European project does not fundamentally differ from the use of the past for nationalist ambitions. Europeanism could thus be regarded as a contemporary scaled-up version of nationalism.

As a corollary, the approach to Europeanism follows in broad lines the archaeological debate on nationalism which has developed in recent years. The critical analyses of nationalist ideas in archaeology that have recently been published in such well-known edited volumes like Kohl and Fawcett's Nationalism, politics and the practice of archaeology (1995) and DíazAndreu and Champion's Nationalism and archaeology in Europe (1996) could thus be directly translated to a European level. In this context, Gramsch argues for a systematic application of what he calls 'reflexive theory.'

No matter how fascinating the issue, it equally appears that the political role of archaeology in the creation of a common European identity should not be exaggerated either-a point stressed by Kaeser in his commentary. This relates to structural changes within the European post-national agenda. Ever since 1992, when the Maastricht Treaty sought to distance itself of the ideal of a supranational, federally organized Europe, the European Union has been looking for a new finalité politique. The concept of a European Union as a common market with a centralist bureaucracy and a poor democratic legitimacy misses a well-defined political future. Hence the quest for a new political concept that would provide a firm ground for deepening and expanding the European Union in the near future. Especially in circles around the 'Third Way' movement (Ulrich Beck, Anthony Giddens), there is considerable reflection about a new transnational order with which the dominant economic structure of the free market and the process of globalization can be conceived of. In this context, a new unifying narrative for Europe has recently been formulated, one that is no longer based on a 
shared mythical past but on a common set of moral values. Europe is discovered as a community of values. Next to market and management, morality is from now on the central concept of European unity. How vigorous this concept's legitimizing function in politics can be has become apparent through the military 'humanitarian intervention' in Kosovo and the diplomatic isolation of the European member state Austria. In both cases, the territorial integrity of a sovereign nation has been subjected to a new doctrine of morality and human rights. This development implies a more modest role for archaeology in the search for a common European identity.

However, such an awareness does not end the debate on Europeanism as a political and cultural ideology. It probably only changes its content and direction. Perhaps critical-reflexive archaeologists should be less concerned about the potential abuse of archaeology in the creation of a European identity on a nationalistic model, i.e. based on descent, exclusiveness and cultural superiority, because the construction and the political use of a European canon of values is not an immediate theme of archaeological research. Europeanism has, however, more aspects which deserve critical consideration. In this issue, Tzanidaki's contribution and Willems' commentary deal with the European Union's growing involvement with the institutional organization of the archaeological heritage on the level of individual member states. In terms of heritage management, the 1992 Valletta Convention (Malta) has had far-reaching effects. On the one hand, these consequences are unmistakably positive because they come down to a durable preservation of archaeological sites and the financing of necessary excavations following the principle that the destroyer pays ('the instigator principle'). On the other hand, Malta has also had negative effects. In the Netherlands, for instance, the introduction of 'Malta' has led to the emergence of contract archaeology which, through a specific set of political decisions, is now strictly bound to the government's policy of town and country planning. As a consequence, archaeology has become the most politicized discipline within the humanities. It goes without saying that Dutch archaeology benefits from this situation in terms of job opportunities, finances and status. But for archaeology as an academic discipline the prospects are rather grim, not in the least because of the growing divide between scientific and marketoriented archaeology (which is also noted by Willems).

We believe that these institutional and scientific consequences of the European heritage management could entail an important theme for a critical-reflexive approach of Europeanism as a political ideology. Kaeser argues in this context for a heightened awareness not just of how archaeology is ideologically consumed in museums and exhibitions, but also how its very knowledge is politically constructed inside the field.

A final and equally important theme is the analysis of Europeanism in terms of culture and identity politics. Which view of being human is implied by Europeanism? What does this mean, 'becoming European'? Are we supposed to become citizens in a political democracy, enjoying political and civil rights and participating in a recognizable political-cultural community, or are we in the first place regarded as consumers in a European supermarket? And what is the role of archaeology in all this? Does this imply a potential reassessment of national frameworks? In this context, Tzanidaki's concluding remarks on the European interference with national and regional culture politics are essential. (DVR/JS) 